\title{
A Journey From Abandonment to Awakening of Jewishness in the Fixer
}

\author{
Fang Xiang ${ }^{1}$ \\ ${ }^{1}$ School of Foreign Languages and Cultures, LeShan Normal University, Leshan, Sichuan Province, China \\ Correspondence: No. 402, Unit 2, Jinling, Mantingfang, No. 778, Xiaoba Road, Leshan City, Sichuan Province, \\ China. Tel: 86-136-7961-3676. E-mail: 44653664@qq.com
}

Received: September 13, 2018 Accepted: October 13, 2018 Online Published: October 15, 2018

doi: 10.5539/elt.v11n11p110 URL: http://doi.org/10.5539/elt.v11n11p110

\begin{abstract}
Jewish identity, carrying the historical significance and sense of mission of Jewish people, is rather serious and contradictory to Jews. This thesis tries to analyse Yakov's journey from his abandonment of Jewish identity to his awakening of Jewishness and his spiritual growth, from his pursuit of exterior freedom to the freedom of all Jews through his suffering in prison and his fighting against those anti-semitic.
\end{abstract}

Keywords: Jewishness, Jewish identity, freedom, awakening

\section{Introduction}

The Fixer, one of great and appealing novels in Jewish American literature, winning two outstanding awards in American literature in 1967, one is American National Book award, another Pulitzer prize. Helterman (1985) explored this book from a moral perspective and interpreted the protagonist Yakov' discovery of his responsibility for his people. Hershinow (1980) explored the character's alienation and aggression under the cruel persecution, and explored the human suffering caused by injustice and charted the spiritual growth and freedom. Though the two critics explored the protagonist' growing in the suffering in prison, they didn't analyze his change from the perspective of Jewish identity which was very subtle to Jews, for Jewish identity meant exile, persecution and suffering. In fact, Jewish identity is one important theme Malamud likes to explore in his novels, therefore this thesis will explore this novel from the Protagonist' attitude toward Jewish Identity.

The Fixer is set in Tsarist Russia at the early 20th century and relives a collective memory of persecution of Jews based on the protagonist-Yakov Bok's suffering in an anti-Jews circumstance.The Fixer is an epitome of persecution of Jews, and also a struggling journey for pursuing freedom. Protagonist, YaKov Bok ("goat" in German) suggests his miserable life and the fate as a scapegoat he does become in a government's plot to charge the Jews of Russia with the ritual murder of a Christian child (Helterman, 1985: 66). The novels spent two thirds pages describing the cruel persecution on him in prison for the stigmatized accusation and recorded his painful journey to his spiritual freedom and growth.

\section{Abandoning Jewish Identity}

Yakov Bok, a Jew who was defeated by his miserable life-- his father and mother died early, he had no child, his wife left home, and his life was impoverished. All the sufferings like massacre, rejection, and contempt Jewish people experienced in their history were caused by Jewish identity, therefore Jewish identity was only a burden to Yakov, for it only brought troubles to him. Accordingly, he lost his belief in God in his struggle for the survival. His estrangement from Jewish people is first manifested in his act to cut his beard which was mocked by other Jews as non-Jew, and his father-in -law Shmuel scolded him "you cut your custom, you are not like your ancestors." Though Shmuel also underwent many miseries in his life, he was still faithful to the God. Shmuel warned Yakov his behavior separated him from his people, but Bok never felt unhappy about it. His deviation from his people was also revealed in his decision to leave the town which was inhabited by the Jews for Kiev to look for good luck. Shmuel also warmed him of the danger of leaving Jews congregation, and told Bok "if you want to go to foreign parts, Turks or no Turks, why not to Palestine where a Jew can see Jewish trees and mountains, and breathe the Jewish air? If I had half a chance there's where I'd go"(Malamud, 1966: 15). Before Bok departed, Shmeul gave him a shawl and a Bible which could remind Yakov of bearing God in his heart. To Yakov, God never favored the Jews-- the so called his chosen people, for the Jews suffered too much in their life, among which the most miserable was they were deprived of their homeland and had to wandered in different 
places in the world and constantly struggled for a humble living. "We live in a world where the clock ticks fast while he's on his timeless mountain staring in space. He doesn't see us and he doesn't care. Today I want my piece of bread, not in Paradise" (Malamud, 1966: 19). At the beginning, Yakov, different from his father-in-law who was faithful to Jewism, decided to look for his freedom and a good life by escaping to Kive. Freedom in Yakov's eyes is to stay far away from Jewish identity and Jews.

Denying one's identity means deliberately forgetting one's history. For the calamities, persecutions, and prejudice Jews suffered when they lived in other countries, Jewish identity was more of a heavy burden on the Jewish people. Whether the ghetto or Jewish identity, they were like a prison and a painful memory suppressed Yakov who thought casting off them meant a way to his freedom, so he concealed his identity when he arrived at Kiev. The irony was he rescued an old man with Double Eagle emblem of the virulently anti-Semitic organization, Black Hundreds. What's more he received a job from this anti-Semitic old man and lived in an anti-Semitic district. However, could concealing his identity really save him and promise him a good life? Though receiving the job provided basic life material to him temporarily, his was in a state of horror all day for fear that his identity would be discovered by other people, therefore he often had nightmare in his dream " the stable in flames, burning down with him in it, bound hand and foot unable to move; and the maddened horses destroying themselves. He dreamed what worried him most- to be unmasked as a hidden Jew"(Malamud 1966:60). At last he found there was no possibility for him to escape from Jews and cast off his identity. Unfortunately, He was accused of murdering a child to collect blood for celebrating Jewish ritual Pesach. His constant fear was convinced that finally he was sent to the prison for his identity as a Jew.

\section{Yakov's Growth and Pursuit of Freedom in the Prison}

In prison, after more than two years' desperate waiting, suffering and fighting, at last, he gained his spiritual growth and freedom. When he was first put into prison, he had to admit his identity as a Jew but claimed his innocence before the attorney. Yakov emphasized his lack of religion and himself a free thinker by which he thought he would be freed from the prison for he was an innocent man. But in fact, as a Jew, he was unable to get his freedom by claiming his estrangement from his people and Jewishness. Until last, he understood that only through committing to his people and history, he could be saved and realized his true freedom.

\subsection{Yakov's Despair in the Prison}

Nowhere is Malamud relentless in stripping away all the props a man has to defend himself against the demons of fear, loneliness, and even madness (Helterman, 1985: 69). First, Yakov is systematically deprived of human society and other people's help for compassion and self-definition.

When Yakov was in prison in the early period, he harbored the idea that he could depend on someone for help and compassion. He made one friend with a prisoner Gronfein who promised to send his letter containing his story to the Jews and thus could save him, but finally this guy betrayed him and sent the letter to the prison authorities, and consequently Yakov was removed from the general prison to a solitary prison. Then Yakov placed all his hope on Bibikov, the investigating magistrate, a kind man who believed in Yakov's innocence. Bibikov knew but unable to prove that the child's mother Marfa Golov and her lover were the real murderer of the child. Bibikov's exhausted effort to find out evidence to testify the innocence of Yakov and save him led to his own imprisonment. But Bibikov failed to handle the high pressure placed on him by the corrupt government and chose to commit suicide. In this novel, any surface freedom is deceiving (Helterman, 1985: 70). Yakov discovered Bibikov's death when the cell was deliberately open by the guard, he sneaked out and saw the secret. Bibikov's death almost destroyed all Yakov's hopes and crushed him, and since then he lost the only external support and entered into a new phase.

\subsection{Yakov's Understanding of Freedom of Spinoza's Theory}

Yakov gained spiritual growth and freedom through two phases. The first phase is through his reading of Spinoza, a great philosopher on freedom. Another is from his indomitable and tough fighting against the authorities in the prison. Spinoza's philosophy on freedom attracted Yakov and inspired him a lot. Interest in Spinoza bound Bibikov and Yakov together, but their understanding on the freedom was different. In Bibikov's mind, Spinoza's thinking on freedom is concerned about the fate, the country, and politics. "He also thought man was freer when he participated in the life of society than when he lived in solitude as he himself did. He thought that a free man in society had a positive interest in promoting the happiness and intellectual emancipation of his neighbors" (Malamud, 1966: 73). Here Bibikov connected freedom with politics and the whole people's happiness. To him, only through realizing freedom and peace in politics, can human beings gain freedom. This was the reason why Bibikov spent no effort to help Yakov at the risk of his own life, but when he was put into prison, he crashed at the corrupt government and chose suicide. On the contrary, Yakov had a different comprehension of Spinoza's 
theory. In his opinion, Spinoza's main idea was human beings should tries all means to get freedom, and freedom meant gain insight into the essence, and connect all things together. "If you are in God's heart, then you are free. But simultaneously, the fate always thwarted your freedom, and you struggled against your fate all the time." The controversy between belief in God and fate led Yakov reached this conclusion "If you understand that a man's mind is part of God, then you understand it as well as I. In that way you're free, if you're in the mind of God. If you're there you know it" (Malamud, 1966: 72). To pursue freedom, Yakov shaved his beard, left the town where he dwelled, and concealed his real identity. But ironically, he was put into prison for his Jewish identity, and lost the essential freedom as a normal people. This caused him to think about what on earth was the freedom, and he found his calamity might be brought by his disbelief in God who punished him in this way. So in this period, he didn't really understand the meaning of freedom and just equaled it with the belief in God.

\subsection{Spiritual Freedom Yakov Gained in His Suffering and Fighting}

The real spiritual freedom he obtained was through his suffering and fighting against the authorities in the prison. Because of the suffering and fighting, he overcame his horrors as a Jew embedded in his heart all the time and grew to be a hero defending his Jewish people at the risk of his freedom.

Indictment of Yakov's case was continuously delayed by Grubbeshov, the representative of the authorities who were anti-Semitism. This murder case was misused by Tsar to shift the political conflict in Russia to Jews, and was taken as a chance to persecute the Jews. Therefore imprisonment of Yakov was a scheme to impose the murdering crime on Jews, and Yakov was just a scapegoat in the case. In this sense, Yakov's action and choice would not only determine his own fate, but also eventually influence the fate of Jews in Russia.

YaKov's suffering could be divided into different phases. In the first place, he lost his freedom because of frame-up crime and placed all hope on release if he was testified as innocent as he was. The death of Bibikov and delaying of indictment crashed his hope and he underwent cruel physical deprivation afterwards. Yakov was imprisoned in a separate black cell, prohibited from any contact with other people and exterior environment, by which way authorities tries to undermine Bok's spiritual strength. When Yakov refused to confess his crime in this murder, the authorities also continued to delay indicting him and executed various physical abuse on him, and hence Yakov's expectation of getting freedom seemed like an illusion. Moreover, Yakov underwent many inhuman treatments which trained him to be strong and indomitable. Yakov was stripped search everyday, sometimes twice or three time a day, by which the authorities wanted to destroy his hope, dignity and will. Yakov gradually reached his spiritual growth in the suffering and proceeded to win a number of small triumphs. The first triumph was when he found what caused his mental and physical weakness was the poisonous food, he didn't compromise but fought against it by stopping having meals until they promised him to have the same meal as other prisoners. Since he was not afraid of death, he gained the power to control his own fate. In order to weaken Yakov's will, they sent Yakov to a dark and separate cell, where Yakov knew nothing about the time and desperate to spent his time in a meaningful way. He tried to clean every corner of the cell with a worn broom everyday. In order to gain some consciousness of the time, he used broom-straws to mark the days, weeks, and months. Through this way, he attempted to build some order out of nightmare and kept himself conscious in this extreme situation.

\section{Awakening of Jewishness}

Yakov gained his own power through silent fighting, and his persistence in regaining his freedom also brought high pressure to the authorities. Both the Prison Wardon and Grubeshov, the Prosecuting Attorney became uneasy when they failed to force Yakov to confess the crime. Though Yakov declined physically for the coldness, hunger and desperate loneliness, he rapidly gained a moral strength that overwhelmed his captors. Besides, Yakov's Jewish consciousness was awakened in this suffering.

When Grubeshov threatened Yakov by noting that Jewish people might be confronted themselves with a new massacre if Yakov failed to confess his crime, and offered Yakov a chance to escape to Europe on the condition that he confessed it, Yakov was not frightened by his threat, but on the contrary, he became aware of the connection of such case with the fate of Jewish people and thus bound his fate with that of Jewish, so he refused Grubeshove and chose to stay in the prison rather than accept the chance to escape.

Yakov showed little respect for God for he thought God didn't care for Jews, now after undergoing the unimaginable physical and mental tortures, Yakov was more critical and rational in thinking about the relationship between Jews and God. Suffering for Jews was not just a test, but also the life itself. Jews were punished by God, because Jews didn't always worship God. They made a covenant with God, but broke the rules to gain their experience. Did Yakov repeat the same pattern as Yakov for gaining his own experience and freedom, and thus got his punishment? Suffering was the only way for the Jews to pursue their experience and 
knowledge. When his father-in-law Shemuel came to see him at the risk of his life, Shemuel still persuaded him to pray on God who could finally save him "God create light, create the world, and us. The real miracle came from belief" (Malamud, 1966: 232). For Shemuel only God could give their mercy and freedom. Yakov didn't place any hope on God, for if God really exists, then he could stop the bloody massacre and protect Jews from constant suffering. But God was far from learning the pains of Jews, let alone rescue them. Yakov gradually reached his spiritual freedom in the prison after many endurance. He refused two chances of release from the prison. One was when a priest came to offer him the chance to get freedom if Yakov promised to convert to the Orthodox. Yakov didn't say any word, but wrapped a shawl used for praying on his head, which meant he would not betrayed his own people and religion. Another one was when a lawyer told him that he would be released because Tsar would release many criminals for memorizing the three hundred anniversaries of Nomandis power, Yakov refused this mercy for the chance was based on his confession of the crime. If he confessed the crime, it meant the crime would be imposed on Jews, which would incur real calamity to Jews. Yakov claimed for the just indictment which could give him innocence and real freedom, if they commanded him to leave the prison without indictment, he would rather choose death. In this sense, freedom in Yakov's view was not an exterior freedom, but a thorough freedom; it was not just his own freedom, but the freedom of the Jewish people. Until now, he began to relate his fate with the fate of Jewish people, which meant his attempts to identify with Jewish identity.

No matter what kinds of temptation the authority gave Yakov, he still insisted on fighting for his freedom through a just and public way, which agitated the authority. Hence Yakov received the cruel treatment which made Yakov would rather choose death. In winter, he stands on the floor without shoes, his foot frozen; in the coldest days, he had to lied on the stone bed and was too cold to fall into sleep with only a thin and worn blanket; When he lied on bed, his feet were shackled with iron chains; in day he would endure the inhuman stripped search. Sometimes it seemed that committing death might be a convenient way to end his suffering, but at last he gave up this idea. When he chose to live rather than death, he chose the mission of saving and protecting Jewish people. He knew that his death would bring disaster to the Jewish people, and the crime would be imposed upon them.

To the goyim what one Jew is is what they all are. If the Fixer stands accused of murdering one of their children, so does the rest of the tribe. Since the crucifixion the crime of Christ-killer is the crime of all Jews. All he can do is not make things worse. He's half a Jews and live in the world like men. He is against those who are against them. He will protect them to the extent that he can. This is his covenant with himself. If God's not a man he has to be. Therefore he must endure to the trial and let them confirm his innocence by their lies. (Malamud, 1966, pp. 245-256).

Since here, Yakov didn't escape his Jewish identity anymore, and connected the suffering with the fate of Jewish people. Death would end his pains, but made all the suffering meaningless. Yakov finally gained the ultimate freedom when he rejected suicide as an alternative and chose to live.

Yakov's persistence won him the chance of indictment. When he was brought out of Prison, he even imagined a conversation with Nichola and even at last his shooting at Tsar. The end didn't reveal the Yakov's fate to us, but Yakov realized his true freedom "there's no such thing as an unpolitical man, especially a Jew. You can't be one without the other, that's clear enough. You can't sit still and see yourself destroyed" (Malamud, 1966: 299).

\section{Conclusion}

Yakov at last learned to a Jew, freedom cannot be separated with politics. There is no freedom without fighting. In the past, freedom to Yakov was to break with Jewish identity which brought catastrophe to the Jewish people . But now Yakov knew that it was impossible for him to separate from the Jewish people and his identity. When he attempted to conquer the authority and gained spiritual freedom, he identified with his Jewishness. Being a Jew, there is no way for you to escape. The only way to win freedom is to fight against any power which means to destroy the Jewish people. Through the suffering and constant fighting, Yakov changed from a coward to a hero of Jews.

\section{Acknowledgement:}

This paper is supported by the grant of the Project of Sichuan federation of social science association : Study on Bernard Malamud's Works from the Perspective of New Historicism. Project No. (SC16XK10).

\section{Reference}

Helterman, J. (1985). Understanding Bernard Malamud. Columbia: University of South Carolina Press.

Hershinow, S. J. (1980). Bernard Malamud. New York: Frederick Ungar Publishing Co. 
Lee, R., \& Mare, E. (2008). The Columbia History of Jews and Judaism in American. New York: Columbia University Press.

Malamud, B. (1996). The Fixer. New York: Penguin Books Ltd.

\section{Copyrights}

Copyright for this article is retained by the author(s), with first publication rights granted to the journal.

This is an open-access article distributed under the terms and conditions of the Creative Commons Attribution license (http://creativecommons.org/licenses/by/4.0/). 